\title{
Rational combinations of immunotherapeutics that target discrete pathways
}

\author{
Stefani Spranger ${ }^{1}$ and Thomas Gajewski ${ }^{2^{*}}$
}

\begin{abstract}
An effective anti-tumor immune response requires the coordinated action of the innate and adaptive phases of the immune system. Critical processes include the activation of dendritic cells to present antigens, produce cytokines including type I interferons, and express multiple costimulatory ligands; induction of a productive T cell response within lymph nodes; migration of activated T cells to the tumor microenvironment in response to chemokines and homing receptor expression; and having effector T cells gain access to antigen-expressing tumor cells and maintain sufficient functionality to destroy them. However, tumors can become adept at escaping the immune response, developing multiple mechanisms to disrupt key processes. In general, tumors can be assigned into two different, major groups depending on whether the tumor there is an 'inflamed' or 'non-inflamed' tumor microenvironment. Improvements in our understanding of the interactions between the immune system and cancer have resulted in the development of various strategies to improve the immune-mediated control of tumors in both sub-groups. Categories of major immunotherapeutic intervention include methods to increase the frequency of tumor antigen-specific effector $T$ cells in the circulation, strategies to block or uncouple a range of immune suppressive mechanisms within the tumor microenvironment, and tactics to induce de novo immune inflammation within the tumor microenvironment. The latter may be particularly important for eliciting immune recognition of non-inflamed tumor phenotypes. The premise put forth in this review is that synergistic therapeutic effects in vivo may be derived from combination therapies taken from distinct "bins" based on these mechanisms of action. Early data in both preclinical and some clinical studies provide support for this model. We also suggest that optimal application of these combinations may be aided by appropriate patient selection based on predictive biomarkers.
\end{abstract}

Keywords: Cancer, Immunotherapy, Interferon, PD-1, PD-L1, CTLA-4, Tumor-associated antigen, Indoleamine-2, 3,-dioxygenase, Denileukin diftitox, Regulatory T cell

\section{Introduction}

With a more detailed understanding of the interactions between the human immune system and cancer, and a larger armamentarium of immunotherapeutic agents in development than ever before, the field of tumor immunotherapy is growing rapidly. Progress will depend upon rational patient selection and logical development and application of these novel therapies, alone or in combination with other treatments. This review summarizes the mechanistic steps involved in the generation and regulation of anti-tumor immune responses, considers discrete categories of immunotherapies based upon type and temporal -

\footnotetext{
* Correspondence: tgajewsk@medicine.bsd.uchicago.edu

${ }^{2}$ Department of Pathology and Department of Medicine, Section of Hematology/Oncology, The University of Chicago, 5841 S. Maryland Ave., MC2115, Chicago, IL 60637, USA

Full list of author information is available at the end of the article
}

spatial aspects of the biologic step being regulated, describes opportunities for selection of patients most likely to benefit from immunotherapy, and suggests immunotherapy combinations that may be attractive for clinical investigation based on logical subdivisions.

\section{The generation of spontaneous anti-tumor immune responses}

Although the theory of immune surveillance remains controversial [1,2], certain pieces of experimental and observational evidence support its existence. The observation that endogenous interferon gamma (IFN- $\gamma$ ) and also IFN $-\alpha / \beta$ can contribute to protection against the growth of methylcholanthrene-induced fibrosarcomas implies that IFN signaling plays a key role in the immune protection against murine cancer [2-4]. Furthermore, human cancer incidence is increased in patients who are immunosuppressed

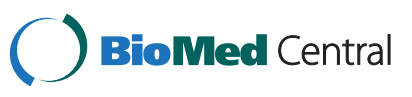


or have immunodeficiencies [5-7] compared with healthy hosts. It has also been observed that melanoma and other cancers can be transmitted from organ transplant donors to recipients, once the organ recipient is immunosuppressed [8]. In light of these data, the premise remains that the immune system can contribute to control of cancer development and/or progression. As a tumor does develop, immune sensing and subsequent immune-mediated control passes through multiple physiological phases, each of which is tightly regulated.

The development of an anti-tumor response is a coordinated, multifaceted phenomenon comprising both the innate and adaptive phases of the immune system (Figure 1). The complex nature of this response, combined with our growing understanding of the process, offers several opportunities for clinical intervention. A brief working model of the generation of an anti-tumor immune response is summarized below.

\section{Role of the innate immune system}

Currently, it is hypothesized that sensors expressed by innate immune cells (e.g., dendritic cells [DC]) can detect damage-associated molecular recognition elements, likely derived from dying cancer cells that result in productive DC activation. This leads to expression of multiple chemokines that recruit additional cell types, and also upregulates expression of multiple costimulatory ligands and secreted cytokines that promote $\mathrm{T}$ cell activation. In the mouse, data suggest that the subset of DCs responsible for cross-presentation of antigen to $\mathrm{T}$ cells in a class I major histocompatibility complex (MHC)restricted fashion is the $C D 8 \alpha^{+} \mathrm{DC}$ subset $[9,10]$. Indeed, Batf $^{-1-}$ mice that are deficient in this lineage fail to generate a spontaneous anti-tumor $\mathrm{T}$ cell response $[10,11]$. The phenotype of the corresponding DC subset in humans has recently been elaborated, as defined by the expression of DNGR1 [12], and investigation into

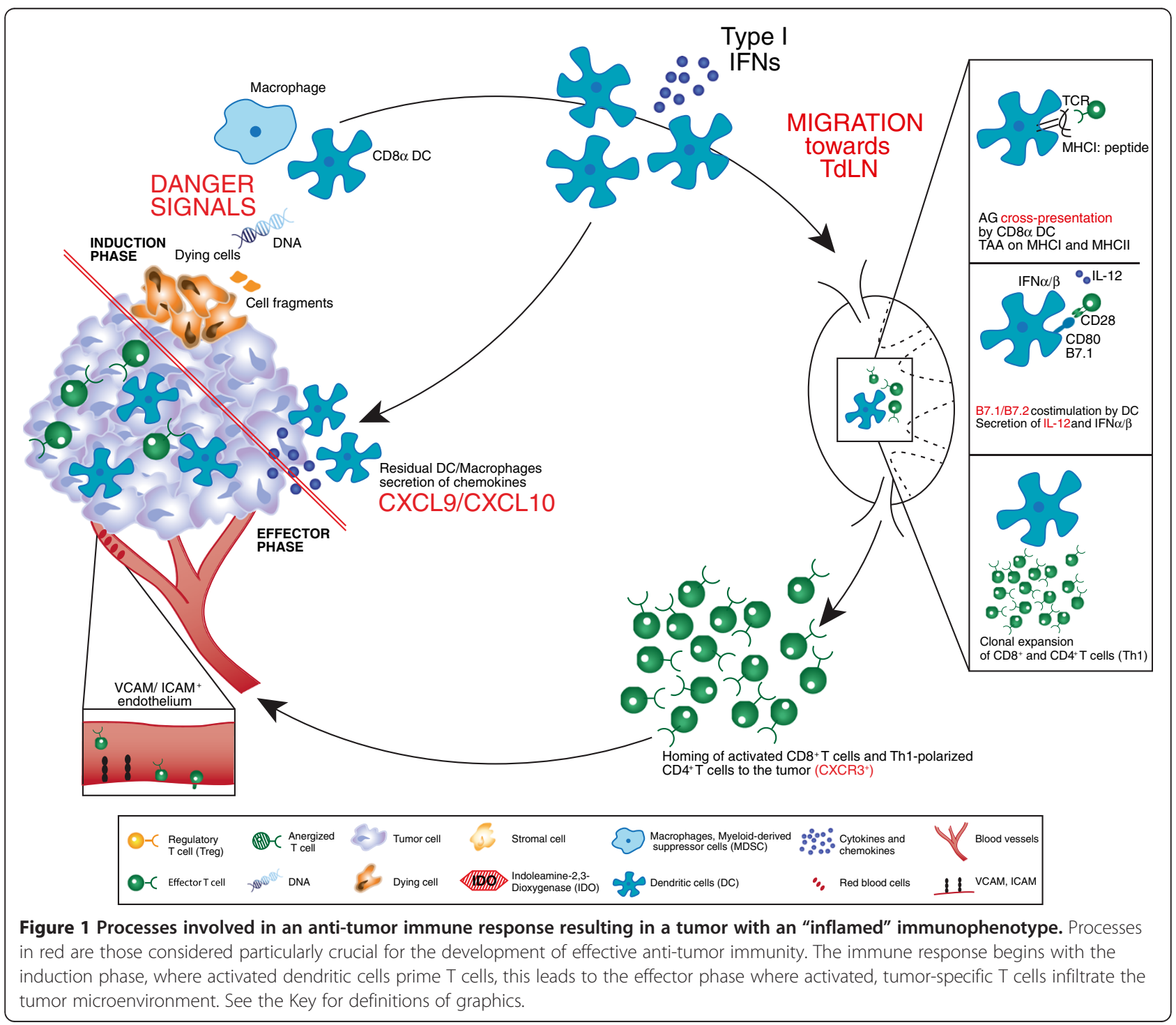


the involvement of this DC subset in human tumors is being evaluated. Interestingly, the activation of those DCs depends, at least in part, on the induction of IFN $-\alpha / \beta$ production in response to a growing tumor $[11,13]$. Type I IFN receptor ${ }^{-/}$mice, or mice deficient in the downstream signaling molecule Stat1, also fail to prime a spontaneous anti-tumor $\mathrm{T}$ cell response $[11,13]$. The innate immune sensing pathway, as well as the tumor-derived ligand(s) responsible for type I IFN production, are being elucidated and are topics of active investigation.

\section{Role of the adaptive immune system}

Once DCs are properly activated in response to a growing tumor, the induction of productive $\mathrm{T}$ cell responses against tumor-associated antigens depends on several molecular elements. Antigen cross-presentation that depends on TAP transporters and class I MHC is critical [14], and recent work has suggested that the receptor Clec9a, highly expressed by CD8 $\alpha^{+} \mathrm{DCs}$, is involved with proper antigen processing $[15,16]$. Expression and costimulation by CD80/CD86 by host cells is required [14], as is production of interleukin (IL)-12 [17]. Mice deficient in any of these factors show poor T cell priming and defective immune-mediated tumor control.

At the effector phase of the anti-tumor $\mathrm{T}$ cell response, activated $T$ cells must traffic to the tumor microenvironment. This process likely depends on the local production of specific chemokines, such as CXCL9 and CXCL10 [18]. In addition, it is thought that the vascular endothelial cells must be activated and express key homing receptors, such as ICAM- 1 and VCAM-1, for T cells to transit into the tumor tissue. Buckanovich and colleagues have identified the endothelin $B$ receptor as one regulator of this process [19]. Evidence suggests that both $\mathrm{CD}_{4}^{+}$and $\mathrm{CD} 8^{+}$effector cells can participate in the effector phase of the anti-tumor immune response $[14,20]$. Once present within the tumor site, activated T cells must maintain their functional properties (cytolytic activity, inflammatory cytokine production, and likely proliferation) and also gain access to individual antigen-expressing tumor cells. Therefore, features of the tumor microenvironment can have a major impact on whether activated $\mathrm{T}$ cells can effectively destroy a tumor. Based on this model, it is not difficult to imagine that immune escape by cancers might be attributed to defective $T$ cell trafficking, suppression of $\mathrm{T}$ cell function, or physical limitation of access to tumor cells. However, the mechanisms of immune escape might be distinct in different patients with the same cancer and in patients with different cancer histologies.

\section{Review}

Strategies to increase the frequency of anti-tumor T cells One of the longest pursued approaches to improve immune-mediated control of cancer is via strategies to increase the number of effector $\mathrm{T}$ cells that can potentially recognize and destroy tumor cells in vivo. These strategies involve both quantitative and qualitative considerations.

\section{Vaccines}

In contrast to classical prophylactic vaccines with the goal to induce an immune response before encountering the antigen, anti-tumor vaccines aim to augment immune responses with the antigen-expressing targets already present. In addition, while prophylactic vaccines largely aim to induce neutralizing antibodies, therapeutic cancer vaccines principally target induction of antigenspecific $\mathrm{T}$ cells. The general composition of vaccines includes a source of tumor-associated antigen (TAA) and an adjuvant component that results in activation of DCs for productive presentation. A wealth of TAAs has been molecularly defined, and this topic has been extensively reviewed [21-25]. Antigens can be incorporated into vaccines as defined proteins or peptides; tumor cell-derived preparations of protein, RNA, or crude extracts; whole tumor cells, either irradiated or engineered to secrete cytokines; or recombinant cDNAs engineered into viral or bacterial vectors. The adjuvant component can consist of oil-based formulations, defined toll-like receptor (TLR) ligands, recombinant cytokines, or the natural innate ligands associated with viral or bacterial vectors. Alternatively, to have full control over their maturation status, DCs loaded with antigen directly can be prepared and injected. Immunologic monitoring for a biologic effect of vaccines is typically performed by measuring the frequency of specific $\mathrm{T}$ cells in peripheral blood. The first FDA-approved therapeutic cancer vaccine is sipuleucel$\mathrm{T}$ for prostate cancer, which consists of the prostatic acid phosphatase antigen fused to granulocyte-macrophage colony-stimulating factor (GM-CSF), loaded onto autologous peripheral blood mononuclear cells [26]. The GM-CSF fusion is thought to target antigen-loading onto DCs. Other vaccines in late phase development include the MAGE-3 protein-based vaccine from GlaxoSmithKline (Brentford, United Kingdom) that incorporates TLR4 and TLR9 ligands as part of the adjuvant $[27,28]$; and PROSTVAC $^{\bullet}$ (Bavarian Nordic A/S, Kvistgaard, Denmark), which utilizes recombinant viral vectors [29]. Thus far, the clinical activity of vaccines has been modest as single agents, likely because of downstream resistance mechanisms that overpower the increased $\mathrm{T}$ cell frequency that is induced following immunization. Thus, combination therapies are appropriate to consider with vaccines as resistance mechanisms continue to be uncovered.

\section{Adoptive $T$ cell transfer}

An alternative strategy to increase the frequency of tumor antigen-specific $\mathrm{T}$ cells is through adoptive $\mathrm{T}$ cell 
transfer. The general concept is to expand in vitro large numbers of tumor antigen-specific $\mathrm{T}$ cells, thus bypassing the early stages of endogenous $T$ cell activation. The most successful of these approaches to date is arguably that based on tumor-infiltrating lymphocytes (TIL) developed by Rosenberg and colleagues for melanoma [30,31]. In that strategy, a tumor is resected and TIL are grown out of the tumor explant in vitro. Prior to $\mathrm{T}$ cell infusion, the patient is conditioned with a lymphodepleting regimen, and then is given IL-2 post infusion. Using this approach, response rates of $50 \%$ or greater have consistently been observed. However, it is important to remember that not all patients have TIL grow out or remain clinically stable at the time the expanded TIL are prepared, so the response rate based on the intent-to-treat population is likely to be lower. Alternative strategies for adoptive $\mathrm{T}$ cell therapy include the administration of antigen-specific $\mathrm{T}$ cell clones, either $\mathrm{CD}^{+}$or $\mathrm{CD}^{+}{ }^{+}$[32-34]; engineering autologous $\mathrm{T}$ cells to express a defined $\mathrm{T}$ cell receptor (TCR), either wild-type or mutated towards a higher affinity [35]; or the genetic engineering of novel receptors consisting of a chimera between an antibody molecule and TCR segments (chimeric antigen receptor) for transduction into autologous T cells [36]. Mechanistically, for solid tumors, the infused $\mathrm{T}$ cells still must traffic to tumor sites, penetrate the tumor microenvironment, and remain functional there. Thus, downstream resistance mechanisms may still be rate limiting in many cases. It is thought that the lymphodepleting conditioning regimen may diminish the contribution of some of these inhibitory mechanisms, as discussed further below.

\section{Cytokines for $T$ cell expansion}

If a low level of endogenous $\mathrm{T}$ cell priming has occurred in some patients, then it is reasonable to consider that expansion of those activated $\mathrm{T}$ cells with $\mathrm{T}$ cell growth factors might raise frequencies sufficiently to gain clinical activity. The first cytokine FDA-approved for this purpose is IL-2, for the treatment of patients with metastatic melanoma and kidney cancer [37], although the mechanism of action of this agent in patients has never been firmly established. More recently explored cytokines that act, in part, by expansion of $\mathrm{T}$ cells include IL-7 [38], IL-21 [39], and IL-15 [40]. Interestingly, IL-7 and IL-15 have also been shown to reverse $\mathrm{T}$ cell anergy $[41,42]$, so these cytokines also may theoretically restore the function of $\mathrm{T}$ cells rendered anergic in the tumor microenvironment (a topic discussed further below).

\section{Manipulation of costimulatory pathways that function in secondary lymphoid organs}

Given the critical role for costimulatory receptors in regulating $\mathrm{T}$ cell activation, pharmacologic manipulation of these pathways has continued to be pursued as a therapeutic approach. This includes the development of agonistic agents that ligate positive costimulatory receptors, as well as blocking agents that attenuate signaling through inhibitory receptors. While many of these pathways may be operational downstream in the tumor microenvironment, some are likely dominantly acting in secondary lymphoid structures, as that is where high expression of respective ligands is seen, usually on antigenpresenting cells. The first of these agents approved by the FDA is ipilimumab (Bristol-Myers Squibb, New York, NY, USA), a monoclonal antibody against the inhibitory receptor cytotoxic T-lymphocyte antigen-4 (CTLA-4), for metastatic melanoma [43]. Agonistic antibodies against the positive costimulatory receptors 41BB (CD137) [44] and OX40 [45] also have shown efficacy in preclinical models and are undergoing early phase clinical trial testing in cancer patients. It is interesting to note that these receptors are upregulated on $\mathrm{T}$ cells after initial TCR ligation, so the biologic activity of the above agents is likely limited to $\mathrm{T}$ cells already undergoing antigen recognition. There is concern with engaging costimulatory receptors constitutively expressed on resting $\mathrm{T}$ cells, such as CD28, as this may cause a more global $\mathrm{T}$ cell activation and have increased toxicity. This certainly was observed with an anti-CD28 monoclonal antibody being evaluated as a potential treatment for autoimmunity [46]. The related CD28 family member, inducible T-cell costimulator (ICOS), is inducibly expressed upon $\mathrm{T}$ cell activation, and preclinical data engaging ICOS via expression of ICOS-L in a vaccine preparation have shown anti-tumor effects in vivo [J.P. Allison, personal communication]. Clinical development of agonistic antibodies against ICOS should therefore receive priority. In addition to the activity of anti-CTLA-4 mAb on lowering the threshold for activation of T cells in lymphoid organs, recent data suggest that some anti-CTLA- 4 mAbs also can deplete Tregs within the tumor microenvironment [47].

\section{Targeting immunologic barriers in the tumor microenvironment}

Data accumulated over several years have indicated that at least two major immunophenotypes of metastatic cancer likely exist. One major phenotype is characterized by the presence of activated $\mathrm{CD}^{+} \mathrm{T}$ cells, expression of chemokines, and also indicators of innate immune activation such as a type I IFN transcriptional signature (Figure 2). The other phenotype looks non-inflamed and shows evidence for higher levels of angiogenesis, macrophage-lineage cells, and fibroblasts in addition to cancer cells. It is likely that the major barriers to immune-mediated tumor destruction differ between these two subsets, and early clinical data support this working model. 


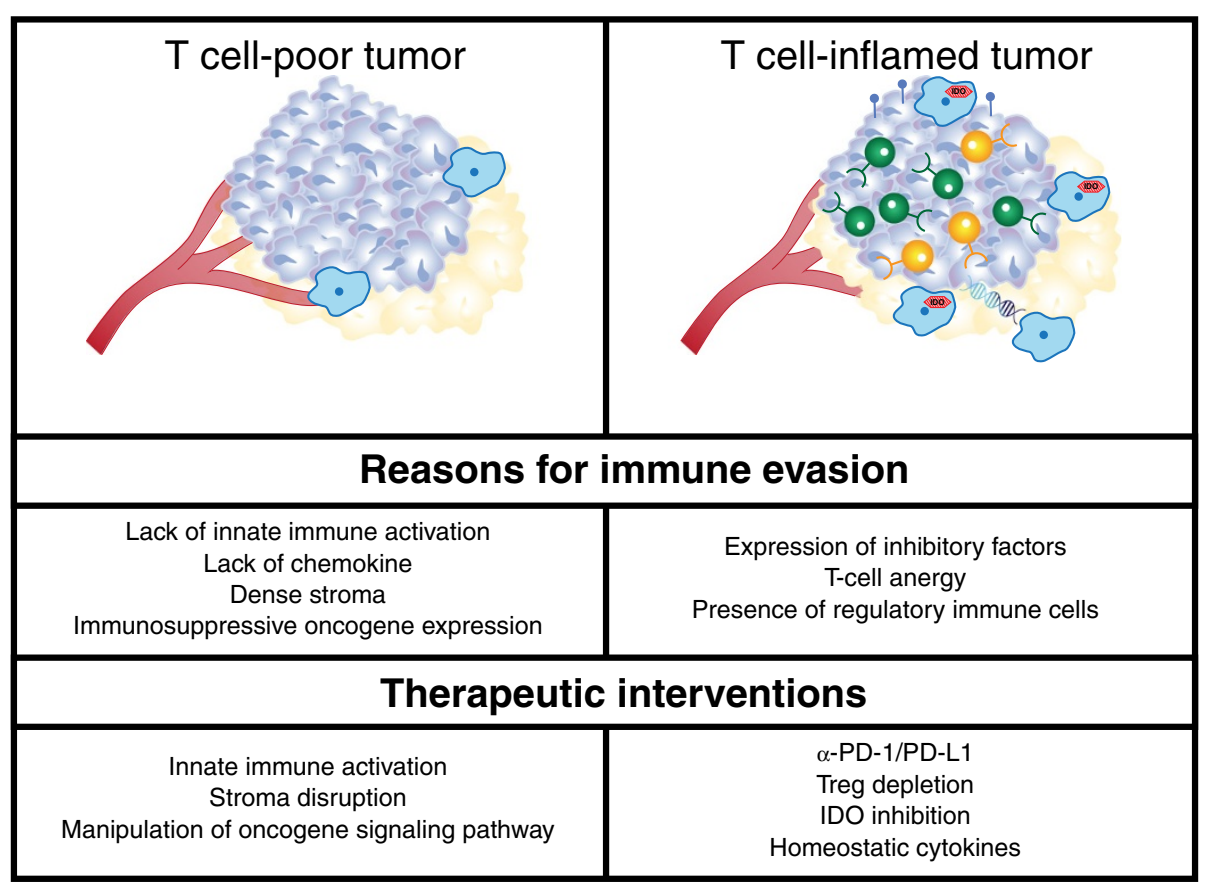

Figure 2 Differences between tumors with "inflamed" and "non-inflamed" immunophenotypes and potential therapeutic interventions. See the Figure 1 Key for definitions of graphics.

\section{Targeting immune inhibitory pathways expressed in $T$ cell-inflamed tumors}

It may seem paradoxical that a subset of tumors can be replete with activated $\mathrm{CD}^{+} \mathrm{T}$ cells yet the tumor is nonetheless growing progressively. In HLA-A $2^{+}$melanoma patients, analysis of small series of samples has indicated that tumor antigen-specific $\mathrm{T}$ cells are among those present, yet these $\mathrm{T}$ cells appear to be dysfunctional [48-50]. Thus, despite the presence of chemokines that have promoted recruitment of activated $\mathrm{T}$ cells, it appears that dominant inhibitory mechanisms have resulted in a loss of function in these cases (Figure 3). Importantly, strategies aiming to block or reverse these inhibitory mechanisms are being pursued clinically. The immune suppressive mechanisms that are best characterized and are farthest along in terms of targeting in the clinic are the inhibitory receptor programmed death 1 (PD-1), which is engaged by the ligand programmed death-ligand 1 (PD-L1, also called B7-H1) expressed by tumor cells; tryptophan catabolism by the enzyme indoleamine-2,3-dioxygenase (IDO); extrinsic suppression by $\mathrm{CD}^{+} \mathrm{CD}^{+} 5^{+} \mathrm{FoxP}^{+}$regulatory $\mathrm{T}$ cells (Tregs); and $\mathrm{T}$ cell-intrinsic anergy or exhaustion, that is best characterized to result from TCR ligation in the absence of engagement of costimulatory receptors such as CD28 $[51,52]$. Recent data in melanoma have revealed that the presence of these immune suppressive mechanisms is highest in tumors that contain infiltrating $\mathrm{T}$ cells, and that activated $\mathrm{CD}^{+} \mathrm{T}$ cells are major mediators of their recruitment. The upregulation of PD-L1 and IDO appear to be driven by T cell-derived IFN- $\gamma$, and the accumulation of Tregs appears to be driven by $\mathrm{T}$ cell-derived chemokines [53,54]. Thus, these major mechanisms of immune suppression in the tumor microenvironment are likely immune-intrinsic rather than directly tumorinduced.

\section{Inhibitory receptors: PD-1/PD-L1 interactions}

PD-1 is an inhibitory receptor inducibly upregulated on activated T cells [55]. The major ligand for PD-1, PD-L1, can be expressed directly on tumor cells. Thus, this receptor/ligand interaction is active within the tumor microenvironment. Preclinical models have demonstrated that blockade of PD-1 or PD-L1, or the use of $\mathrm{PD}-1$-deficient $\mathrm{T}$ cells, can result in profound immunemediated tumor control in many experimental systems [56-59]. Multiple human cancer types have been demonstrated to express PD-L1 in the tumor microenvironment [60]. Clinically, monoclonal antibodies targeting PD-1 or PD-L1 have already shown major clinical activity in phase I/II clinical trials, with response rates around $30 \%$ in patients with melanoma, kidney cancer, and nonsmall cell lung cancer [55,61-64]. These agents also have encouraging safety profiles, although treatment-associated adverse events have included instances of pulmonary toxicity. Phase III studies with nivolumab (anti-PD-1; Bristol-Myers Squibb, New York, NY, USA) monotherapy are ongoing in melanoma, squamous and non-squamous 
non-small cell lung cancer, and kidney cancer. Phase II studies in other malignancies and phase I combination studies with various anti-PD-1 monoclonal antibodies have all been initiated.

In addition to PD-L1, at least two other inhibitory ligands have been reported to be expressed on tumor cells, namely, B7-H3 and B7-H4. Expression of these ligands correlates with poorer outcome or more advanced disease in some tumor types and preclinical data have supported efficacy with blocking antibodies in vivo [65-67]. Clinical development of antibodies specific for human counterparts is warranted.

\section{Metabolic dysregulation: IDO}

$\mathrm{T}$ cell-infiltrated melanomas and other tumor types also appear to show increased expression of the immunosuppressive enzyme IDO. In most tumor types examined, IDO expression has correlated with unfavorable patient prognosis and is associated with advanced stage and tumor metastasis [68]. In normal physiology, IDO metabolizes tryptophan and limits T- and NK-cell activation in local tissue microenvironments, such as the placenta $[69,70]$. IDO expression in preclinical models prevents tumor rejection, and blockade of IDO activity can be immune-potentiating in vivo [71,72]. Two smallmolecule IDO inhibitors are in clinical development, INCB024360 (Incyte Corporation, Wilmington, DE, USA) [73-75] and 1-methyl-DL-tryptophan [76-78]. Phase I clinical trial data presented at the American Society of Clinical Oncology 2012 meeting showed that, in patients treated with INCB024360, biologically active doses were achieved causing a reversal of the tryptophan to kynurenine ratio [76]. Phase II single agent and phase I combination studies have been initiated with these agents.

A second amino acid-catabolizing enzyme expressed in the tumor microenvironment is arginase, which catabolizes arginine [79]. Preclinical data indicate that arginine metabolism is one way in which $\mathrm{T}$ cell dysfunction can occur within the tumor microenvironment, and conditional knockout mice in which arginase is eliminated 
in myeloid cells show improved anti-tumor $\mathrm{T}$ cell responses [79]. However, targeting this enzyme pharmacologically in the clinic might prove challenging due to baseline expression and function in normal tissues.

\section{Suppressive cell populations: Tregs and MDSCs}

In normal physiology, Tregs thwart the development of autoimmunity and curb bystander tissue destruction by limiting ongoing immune responses and maintaining tolerance to self-antigens $[80,81]$. In cancer patients, circulating Treg numbers are reported to be increased compared with normal controls [82-84]. In addition, high numbers of infiltrating Tregs have been observed in the tumor microenvironment in a subset of patients with various cancers. As mentioned above, recent data in melanoma indicate that higher Treg numbers are observed in tumors that have greater infiltration with $\mathrm{CD}^{+} \mathrm{T}$ cells [53]. There are two major populations of Tregs, those that develop naturally in the thymus and those that are induced in the periphery under the influence of TGF- $\beta$ [85]. Our own observations in the B16 melanoma model have revealed that natural Tregs are the major subset recruited into the tumor microenvironment rather than conversion of FoxP3-negative $\mathrm{CD}^{+} \mathrm{T}$ cells [53]. In ovarian cancer, a higher CD8:Treg ratio has been correlated with improved overall outcome [86]. In preclinical models, depletion of Tregs using anti-CD25 monoclonal antibody or by ex vivo anti-CD25 bead depletion has been shown to improve immune-mediated tumor control in vivo [87-89]. Based on these observations, strategies to deplete Tregs in cancer patients are being pursued using a variety of approaches. To date, all of these approaches are focusing on targeting CD25. The IL-2/diphtheria toxin fusion protein, denileukin diftitox (Ontak ${ }^{\circ}$, Eisai Inc., Woodcliff Lake, NJ, USA), has been reported to diminish Treg numbers in the circulation in some studies [90-92], although this has not been observed in all trials [93]. Various doses and schedules are being pursued, and clinical regressions have been reported in melanoma [94]. The anti-CD25 monoclonal antibody daclizumab (F. Hoffmann-La Roche Ltd., Basel, Switzerland) also has been given to advanced cancer patients and has been shown to decrease Treg numbers in the peripheral blood for a prolonged period of time [95]. A third strategy being evaluated involves immune-bead depletion of $\mathrm{CD} 25^{+}$cells from $\mathrm{T}$ cell products prior to adoptive transfer into patients.

In addition to Tregs, a second extrinsically suppressive cellular population that can be active within the tumor microenvironment is represented by myeloid-derived suppressor cells (MDSCs). These cells appear to consist of immature myeloid populations that both support tumor growth and inhibit $\mathrm{T}$ cell activation via a number of mechanisms. This includes the expression and functional activity of arginase [79], and the nitrosylation of surface proteins on infiltrating $\mathrm{T}$ cells, including the TCR [96]. Therapeutic approaches to diminish MDSC number or function are challenging due to difficulties identifying specific pharmacologic targets, but several interventions are being tested in patients with cancer [97].

\section{$T$ cell-intrinsic anergy}

In addition to the above-listed extrinsic mechanisms of inhibition of $\mathrm{T}$ cell function, recent evidence supports a role for T cell-intrinsic anergy as a contributory mechanism of immune evasion in the tumor microenvironment. Classical anergy is a dysfunctional state that results from TCR ligation in the absence of costimulatory receptor engagement [98]. Preclinical and clinical data analyzing TIL in melanoma and other models indicate that purified antigen-specific $\mathrm{T}$ cells remain dysfunctional early after removal from the immune suppressive influence of the tumor microenvironment [48-50]. Early data suggested that introduction of the CD28 ligand B7-1 (CD80) into tumor cells could result in immunemediated rejection in vivo [99-101]. Unlike the extrinsic mechanisms of suppression described above, it has been more difficult to consider targeting anergy therapeutically because of lack of molecular targets suitable for manipulation. However, recent molecular characterization of the anergic state has provided new insights that are relevant for therapeutic intervention. In vitro, anergic $\mathrm{T}$ cells can recover function following proliferation in response to homeostatic cytokines (IL-7, IL-15, and perhaps IL-21) [41]. In vivo, endogenous IL-7 and IL-15 are liberated under conditions of lymphopenia [102,103]. Adoptive transfer of anergic $\mathrm{T}$ cells into lymphopenic recipients can reverse T cell anergy and support tumor rejection [104]. The ability of a lymphopenic environment to maintain $\mathrm{T}$ cell function may explain, in part, the success of TIL-based adoptive transfer regimens that include lymphopenic conditioning [30,31,105].

Recent work has identified the transcription factor early growth response gene 2 (EGR2) as a regulator of the anergic state [106]. EGR2 is upregulated in anergic cells, and in part functions by driving expression of diacylglycerol kinases, which inhibit TCR-induced Ras pathway activation [107,108]. EGR2-dependent gene expression profiling and ChIP-SEQ analysis have revealed additional EGR2 target genes that are functionally important [109]. Some of these encode surface proteins, including LAG-3 and 4-1BB. LAG-3 has been defined as another inhibitory receptor expressed on activated $\mathrm{T}$ cells $[110,111]$, and $4-1 \mathrm{BB}$ is a costimulatory receptor [44,112]. Dysfunctional $\mathrm{T}$ cells in the tumor context also have been shown to express Tim-3, another inhibitory receptor [113]. Preclinical data show that blockade of LAG-3 or Tim-3, or ligation of 4-1BB, can potently augment 
immune-mediated tumor rejection in vivo [114-116]. Taken together, these results suggest that manipulation of these receptors might operate, at least in part, to restore function of anergic anti-tumor $\mathrm{T}$ cells.

\section{Overcoming barriers in non-inflamed tumors}

Tumors that fail to generate a spontaneous anti-tumor $\mathrm{T}$ cell response and lack a $\mathrm{T}$ cell infiltrate may represent a special case from the immunotherapy perspective and could require additional interventions to enable immune recognition. The underlying mechanisms responsible for lack of a $\mathrm{T}$ cell-inflamed tumor microenvironment are not fully understood, but this phenotype correlates with absence of a type I IFN signature and poor chemokine production, suggesting defective innate immune activation and a deficient ability to recruit activated T cells [18,117].

Administration of IFN-alpha had been approved by the FDA for the treatment of various cancers, including melanoma where it is used in the adjuvant setting $[118,119]$. However, systemic administration might not maximize the therapeutic effect as it fails to provide "directionality" to the inflammatory response. Preclinical data from our own laboratory have indicated that intratumoral administration can be more effective (unpublished data). Published preclinical studies support the notion not only that type I IFNs can help promote innate immune activation in the tumor microenvironment [120], but in addition that local application of TLR ligands [121], expression of the tumor necrosis factor superfamily member LIGHT [122,123], and injection of oncolytic viruses [124] also may have utility in this regard. Clinical studies applying these approaches are ongoing or under development but further research into the underlying mechanisms governing the absence of a spontaneous anti-tumor $\mathrm{T}$ cell response in a major subset of cancers is warranted to help guide the development of these therapies with greater precision. The first oncolytic virus tested in a phase III study in melanoma was recently reported to meet the primary endpoint based on clinical response [125]. One challenge facing attempts to modify inflammation in the tumor microenvironment selectively in vivo is to devise strategies for systemic administration of agents that preferentially target tumor sites. One conceptual approach would be the use of tumor-targeting monoclonal antibodies carrying immunoregulatory molecules as a payload. Another barrier for development of these agents is the lack of an ideal mouse model for preclinical development. All transplantable tumor models appear to induce a meaningful degree of inflammation, so the development of a system for non-inflamed tumors may depend on design of a genetic model of suitable oncogene combinations. Ultimately, interventions aimed at initiating inflammation in the tumor site will likely benefit from combinations with therapeutic approaches increasing the $\mathrm{T}$ cell frequency and blocking negative regulatory pathways, as discussed below.

\section{Logical immunotherapy combinations}

Based on the above structural overview, a model for prioritizing combination therapy testing based on distinct categories of regulatory checkpoint emerges. An overview of these considerations is depicted in Figure 4. One can consider two broad categories of patients-those with a $\mathrm{T}$ cell-inflamed tumor microenvironment and a spontaneous anti-tumor $\mathrm{T}$ cell response, and those with a non-inflamed tumor microenvironment and a minimal spontaneous anti-tumor $\mathrm{T}$ cell response. In addition, there are three major "bins" of interventions-strategies to increase systemically the frequency of anti-tumor $\mathrm{T}$ cells (I), strategies to overcome distinct immune suppressive pathways within the tumor microenvironment (II) and strategies to trigger innate immune activation and inflammation in tumor sites (III). The second category can be further subdivided into approaches to block inhibitory receptor engagement (e.g., PD-L1/PD-1 interactions), deplete Tregs, inhibit metabolic enzymes such as IDO, or reverse/prevent $\mathrm{T}$ cell anergy. Because each of these processes is largely regulated independently, one might expect true synergy when they are manipulated in a combinatorial fashion. A corollary is that combinations of interventions that influence the same process or pathway might not be synergistic, although they could conceivably be additive.

Multiple examples of successful immunotherapy combinations have been evaluated in preclinical models and the results are in keeping with the logic of the framework described above. For example, Treg depletion plus homeostatic proliferation in a lymphopenic recipient (to counter $\mathrm{T}$ cell anergy) can have potent activity in some models [14,87]. This can become even more efficacious with adoptive $\mathrm{T}$ cell transfer as a strategy to increase $\mathrm{T}$ cell frequencies [126]. Treg depletion also can be synergistic with some vaccines $[89,95,127]$. Combinatorial blockade with anti-CTLA-4 and anti-PD-1 monoclonal antibodies can be potently synergistic in some tumor models [128]. Anti-4-1BB monoclonal antibodies (which could act in the periphery to increase $T$ cell frequencies or in the tumor microenvironment to restore function of anergic cells) combined with anti-PD-L1 also appear synergistic [59,129], as is combined elimination of LAG-3 and PD-1 function [130] or anti-Tim-3 plus anti-PD-L1 [131]. Preliminary data from our laboratory have indicated that IDO inhibition combined with either antiCTLA-4 or anti-PD-L1 monoclonal antibodies can also result in potent immune-mediated tumor control in vivo [authors' unpublished observations]. However, preliminary experiments with anti-LAG-3 and anti-4-1BB (which 
both may manipulate anergic $\mathrm{T}$ cells) have not shown synergistic effects.

Based on these and other similar preclinical data, several logical combination immunotherapies are already being evaluated in clinical trials. Several therapeutic cancer vaccines are being tested in combination with Treg depletion, using either denileukin diftitox or anti-CD25 monoclonal antibody [75,132-134]. The Cancer Immunotherapy Trials Network is planning to investigate the prostate cancer vaccine sipuleucel- $\mathrm{T}$ along with the homeostatic cytokine IL-7 [http://citninfo.org/citn-science/clinical-studies.html]. The anti-CTLA-4 monoclonal antibody ipilimumab is being tested in combination with an IDO inhibitor [75] and also with nivolumab in a phase III trial in patients with previously untreated metastatic melanoma [135]. Phase I/II data of antiCTLA-4 + anti-PD-1 showed a clinical response rate of over $50 \%$, with more rapid and deep clinical responses than what had been observed historically with either agent alone [136]. TIL-based adoptive T cell therapy has already been shown to be most potent when combined with lymphopenic conditioning of the patient, which is thought to reduce Treg numbers and support homeostatic proliferation of transferred T cells $[30,31,105]$.

The clinical application of multiple immunotherapies in combination will require careful consideration of several factors, including the timing of agent administration (concurrent vs sequential, as previously evaluated), the potential for overlapping/additive toxicities of the individual agents, and particularly the development of synergistic toxicities, including potential sequelae of immune system overstimulation. However, with appropriate adverse-event management, treatments targeting multiple, discrete branches of tumor-associated immunity may have the potential to improve patient outcomes dramatically.

\section{Biomarkers}

The successful application of combination immunotherapies in the clinic may ultimately benefit from appropriate patient selection based upon predictive biomarkers. Based on available data, a leading biomarker for response to current immunotherapies is the presence of an "inflammatory" gene expression signature that suggests an ongoing, smoldering immune response against the tumor. The predictive significance of these signatures has been preliminarily confirmed in several small studies [137-141]. A similar correlation has been reported with nivolumab, in which clinical responses appear associated with expression of PD-L1 in the tumor microenvironment along with a $\mathrm{CD}^{+}{ }^{+} \mathrm{T}$ cell infiltrate $[63,75,135]$. Combination immunotherapies that manipulate the endogenous immune response or involve strategies to increase the frequency of anti-tumor $\mathrm{T}$ cells may all rely on the intrinsic ability of the metastatic tumor sites to recruit effector $\mathrm{T}$ cells into the tumor microenvironment. More specific markers could be envisioned as predictive for benefit to anti-LAG-3, antiTim-3, or anti-4-1BB, for example, based on the presence of $\mathrm{T}$ cells in the tumor microenvironment that are dysfunctional, yet show surface expression of these receptors ex vivo.

In contrast, patients with tumors that are "noninflamed" may respond poorly to most of these immunotherapeutic interventions because there is no spontaneous endogenous immune response to be manipulated, and/or because activated $\mathrm{T}$ cells cannot traffic into the tumor 
microenvironment. Therefore, such patients ultimately might require new strategies to induce appropriate innate immune activation and chemokine production in the tumor microenvironment. One can envision combining these strategies with approaches to increase the frequency of anti-tumor $\mathrm{T}$ cells and/or block negative regulatory pathways in the tumor microenvironment.

\section{Conclusions}

Mechanisms of tumor immune escape are multiple and can compensate for one another, and preclinical models suggest synergy when two distinct mechanisms are manipulated in concert. It is anticipated that logical doublet combinations in the clinic will impart a meaningful impact on patient outcomes. Different cancer types beyond melanoma may have specific dominant mechanisms of suppression (e.g., B7-H3, B7-H4), and therefore could benefit from unique, tailored immunotherapy combinations. Finally, one of the biggest challenges might be to promote $\mathrm{T}$ cell-based inflammation in "non-inflamed" tumors in order to expand the subset of patients in whom currently active immunotherapies appear effective. With a broader arsenal of immunotherapeutic agents and a deeper understanding of tumor-host interactions, clinical tumor immunotherapy is poised to advance significantly. Careful consideration of appropriate patient candidates based on biomarker development and a logical, coordinated application of immunotherapy combinations should accelerate advancement of the field.

\section{Abbreviations}

CTLA-4: Cytotoxic T-lymphocyte antigen 4; DC: Dendritic cell; EGR2: Early growth response gene 2; GM-CSF: Granulocyte-macrophage colonystimulating factor; ICOS: Inducible T-cell costimulator; IDO: Indoleamine-2,3dioxygenase; IFN: Interferon; IL: Interleukin; MDSC: Myeloid-derived suppressor cells; MHC: Major histocompatibility complex; PD-1: Programmed death-1; PD-L1: Programmed death - ligand 1; TAA: Tumor-associated antigen; TCR: T cell receptor; TIL: Tumor-infiltrating lymphocytes; TLR: Toll-like receptor; Treg: Regulatory $T$ cell.

\section{Competing interests}

TG has served in an advisory role for GSK-Bio, Roche-Genentech, BMS, Merck, Abbvie, and Jounce Therapeutics. SS declares no competing interests.

\section{Authors' contributions}

TG and SS both wrote and revised the manuscript, with editorial assistance from Cailin Moira Wilke, PhD, at StemScientific. Both authors read and approved the final manuscript.

\footnotetext{
Acknowledgments

Work from the authors' laboratory described in this review has been supported by R01CA161005, R01CA127475, R01CA118153, P01CA97296, and the Melanoma Research Alliance. SS is a postdoctoral fellow of the German Research Foundation (DFG). Through the course of this work, the authors have appreciated the technical support of Michael Leung, Michelle Gao, Yuanyuan Zha, and Glee Li, as well as infrastructure support through multiple University of Chicago Comprehensive Cancer Center shared resources (Human Immunologic Monitoring and cGMP facilities, Functional Genomics Facility, Human Tissue Resource, and Flow Cytometry Facility). We thank Cailin Moira Wilke, PhD, at StemScientific, who provided medical writing services and editorial assistance on behalf of Bristol-Myers Squibb.
}

\section{Author details}

'Biological Sciences Division, Pathology, The University of Chicago, $929 \mathrm{E}$. 57th Street, GCIS W-423, Chicago, IL 60637, USA. ²Department of Pathology and Department of Medicine, Section of Hematology/Oncology, The University of Chicago, 5841 S. Maryland Ave., MC2115, Chicago, IL 60637, USA.

Received: 20 June 2013 Accepted: 12 September 2013

Published: 23 September 2013

\section{References}

1. Burnet FM: Cancer-a biological approach: I. The processes of control. II. The significance of somatic mutation. Brit Med J 1957, 1:779-786.

2. Dunn GP, Bruce AT, Ikeda H, Old LJ, Schreiber RD: Cancer immunoediting: from immunosurveillance to tumor escape. Nat Immunol 2002, 3:991-998.

3. Dighe AS, Richards E, Old $\amalg$, Schreiber RD: Enhanced in vivo growth and resistance to rejection of tumor cells expressing dominant negative IFN gamma receptors. Immunity 1994, 1:447-456.

4. Ikeda H, Old LJ, Schreiber RD: The roles of IFN gamma in protection against tumor development and cancer immunoediting. Cytokine Growth Factor Rev 2002, 13:95-109.

5. Penn I: Malignant Tumors in Organ Transplant Recipients. In Recent Results in Cancer, Volume 35. Heidelberg: Springer-Verlag; 1970:1-55.

6. Penn I: Posttransplant malignancies. Transplant Proc 1999, 31:1260-1262.

7. Gatti RA, Good RA: Occurrence of malignancy in immunodeficiency diseases. A literature review. Cancer 1971, 28:89-98.

8. Penn I: Malignant melanoma in organ allograft recipients. Transplantation 1996, 61:274-278.

9. Dudziak D, Kamphorst AO, Heidkamp GF, Buchholz VR, Trumpfheller C, Yamazaki S, Cheong C, Liu K, Lee HW, Park CG, Steinman RM, Nussenzweig MC: Differential antigen processing by dendritic cell subsets in vivo. Science 2007, 315:107-111.

10. Hildner K, Edelson BT, Purtha WE, Diamond M, Matsushita H, Kohyama M, Calderon B, Schraml BU, Unanue ER, Diamond MS, Schreiber RD, Murphy TL, Murphy KM: Batf3 deficiency reveals a critical role for CD8alpha + dendritic cells in cytotoxic T cell immunity. Science 2008, 322:1097-1100.

11. Fuertes MB, Kacha AK, Kline J, Woo SR, Kranz DM, Murphy KM, Gajewski TF: Host type I IFN signals are required for antitumor CD8+ T cell responses through CD8\{alpha\} + dendritic cells. J Exp Med 2011, 208:2005-2016.

12. Poulin LF, Salio M, Griessinger $E$, Anjos-Afonso F, Craciun L, Chen JL, Keller AM, Joffre O, Zelenay S, Nye E, Le Moine A, Faure F, Donckier V, Sancho D, Cerundolo V, Bonnet D, Reis e Sousa C: Characterization of human DNGR$1+$ BDCA3+ leukocytes as putative equivalents of mouse CD8alpha + dendritic cells. J Exp Med 2010, 207:1261-1271.

13. Diamond MS, Kinder M, Matsushita H, Mashayekhi M, Dunn GP, Archambault JM, Lee H, Arthur CD, White JM, Kalinke U, Murphy KM, Schreiber RD: Type I interferon is selectively required by dendritic cells for immune rejection of tumors. J Exp Med 2011, 208:1989-2003.

14. Kline J, Zhang L, Battaglia L, Cohen KS, Gajewski TF: Cellular and molecular requirements for rejection of B16 melanoma in the setting of regulatory T cell depletion and homeostatic proliferation. J Immunol 2012, 188:2630-2642.

15. Poulin LF, Reyal Y, Uronen-Hansson H, Schraml BU, Sancho D, Murphy KM, Håkansson UK, Moita LF, Agace WW, Bonnet D, Reis e Sousa C: DNGR-1 is a specific and universal marker of mouse and human Batf3-dependent dendritic cells in lymphoid and nonlymphoid tissues. Blood 2012, 119:6052-6062.

16. Zelenay S, Keller AM, Whitney PG, Schraml BU, Deddouche S, Rogers NC, Schulz O, Sancho D, Reis e Sousa C: The dendritic cell receptor DNGR-1 controls endocytic handling of necrotic cell antigens to favor crosspriming of CTLs in virus-infected mice. J Clin Invest 2012, 122:1615-1627.

17. Fallarino F, Uyttenhove C, Boon T, Gajewski TF: Endogenous IL-12 is necessary for rejection of P815 tumor variants in vivo. J Immunol 1996, 156:1095-1100.

18. Harlin H, Meng Y, Peterson AC, Zha Y, Tretiakova M, Slingluff C, McKee M, Gajewski T: Chemokine expression in melanoma metastases associated with CD8+ T-cell recruitment. Cancer Res 2009, 69:3077-3085.

19. Buckanovich RJ, Facciabene A, Kim S, Benencia F, Sasaroli D, Balint K, Katsaros D, O'Brien-Jenkins A, Gimotty PA, Coukos G: Endothelin B receptor mediates the endothelial barrier to $T$ cell homing to tumors and disables immune therapy. Nat Med 2008, 14:28-36. 
20. Schietinger A, Philip M, Liu RB, Schreiber K, Schreiber H: Bystander killing of cancer requires the cooperation of $\mathrm{CD} 4(+)$ and $\mathrm{CD} 8(+) \mathrm{T}$ cells during the effector phase. J Exp Med 2010, 207:2469-2477.

21. Buonaguro L, Petrizzo A, Tornesello ML, Buonaguro FM: Translating tumor antigens into cancer vaccines. Clin Vaccine Immunol 2011, 18:23-34.

22. Cheever MA, Allison JP, Ferris AS, Finn OJ, Hastings BM, Hecht TT, Mellman I, Prindiville SA, Viner JL, Weiner LM, Matrisian LM: The prioritization of cancer antigens: a national cancer institute pilot project for the acceleration of translational research. Clin Cancer Res 2009, 15:5323-5337.

23. Meek DW, Marcar L: MAGE-A antigens as targets in tumour therapy. Cancer Lett 2012, 324:126-132.

24. Smith HA, McNeel DG: The SSX family of cancer-testis antigens as target proteins for tumor therapy. Clin Dev Immunol 2010, 2010:150591.

25. Straten PT, Andersen MH: The anti-apoptotic members of the Bcl-2 family are attractive tumor-associated antigens. Oncotarget 2010, 1:239-245.

26. Kantoff PW, Higano CS, Shore ND, Berger ER, Small EJ, Penson DF, Redfern $\mathrm{CH}$, Ferrari AC, Dreicer R, Sims RB, Xu Y, Frohlich MW, Schellhammer PF, IMPACT Study Investigators: Sipuleucel-T immunotherapy for castrationresistant prostate cancer. N Engl J Med 2010, 363:411-422.

27. Peled N, Oton AB, Hirsch FR, Bunn P: MAGE A3 antigen-specific cancer immunotherapeutic. Immunotherapy 2009, 1:19-25.

28. Tyagi P, Mirakhur B: MAGRIT: the largest-ever phase III lung cancer trial aims to establish a novel tumor-specific approach to therapy. Clin Lung Cancer 2009, 10:371-374.

29. Kantoff PW, Schuetz TJ, Blumenstein BA, Glode LM, Bilhartz DL, Wyand M, Manson K, Panicali DL, Laus R, Schlom J, Dahut WL, Arlen PM, Gulley JL, Godfrey WR: Overall survival analysis of a phase II randomized controlled trial of a Poxviral-based PSA-targeted immunotherapy in metastatic castration-resistant prostate cancer. J Clin Oncol 2010, 28:1099-1105.

30. Dudley ME, Yang JC, Sherry R, Hughes MS, Royal R, Kammula U, Robbins PF, Huang J, Citrin DE, Leitman SF, Wunderlich J, Restifo NP, Thomasian A, Downey SG, Smith FO, Klapper J, Morton K, Laurencot C, White DE, Rosenberg SA: Adoptive cell therapy for patients with metastatic melanoma: evaluation of intensive myeloablative chemoradiation preparative regimens. J Clin Oncol 2008, 26:5233-5239.

31. Rosenberg SA, Dudley ME: Cancer regression in patients with metastatic melanoma after the transfer of autologous antitumor lymphocytes. Proc Natl Acad Sci U S A 2004, 101(Suppl 2):14639-14645.

32. Yee C, Thompson JA, Byrd D, Riddell SR, Roche P, Celis E, Greenberg PD: Adoptive $T$ cell therapy using antigen-specific CD8+ T cell clones for the treatment of patients with metastatic melanoma: in vivo persistence, migration, and antitumor effect of transferred T cells. Proc Natl Acad Sci U S A 2002, 99:16168-16173.

33. Chapuis AG, Thompson JA, Margolin KA, Rodmyre R, Lai IP, Dowdy K, Farrar EA, Bhatia S, Sabath DE, Cao J, Li Y, Yee C: Transferred melanoma-specific CD8+ T cells persist, mediate tumor regression, and acquire central memory phenotype. Proc Natl Acad Sci U S A 2012, 109:4592-4597.

34. Hunder NN, Wallen H, Cao J, Hendricks DW, Reilly JZ, Rodmyre R, Jungbluth A, Gnjatic S, Thompson JA, Yee C: Treatment of metastatic melanoma with autologous CD4+ T cells against NY-ESO-1. N Engl J Med 2008, 358:2698-2703.

35. Morgan RA, Dudley ME, Wunderlich JR, Hughes MS, Yang JC, Sherry RM, Royal RE, Topalian SL, Kammula US, Restifo NP, Zheng Z, Nahvi A, de Vries CR, Rogers-Freezer LJ, Mavroukakis SA, Rosenberg SA: Cancer regression in patients after transfer of genetically engineered lymphocytes. Science 2006, 314:126-129.

36. Zhao Y, Moon E, Carpenito C, Paulos CM, Liu X, Brennan AL, Chew A, Carroll $\mathrm{RG}$, Scholler J, Levine BL, Albelda SM, June CH: Multiple injections of electroporated autologous T cells expressing a chimeric antigen receptor mediate regression of human disseminated tumor. Cancer Res 2010, 70:9053-9061.

37. Atkins MB: Interleukin-2: clinical applications. Semin Oncol 2002, 29(3 Suppl 7):12-17.

38. Mackall CL, Fry TJ, Gress RE: Harnessing the biology of IL-7 for therapeutic application. Nat Rev Immunol 2011, 11:330-342.

39. Bhave NS, Carson WE 3rd: Immune modulation with interleukin-21. Ann N Y Acad Sci 2009, 1182:39-46.

40. Croce M, Orengo AM, Azzarone B, Ferrini S: Immunotherapeutic applications of IL-15. Immunotherapy 2012, 4:957-969.

41. Boussiotis VA, Barber DL, Nakarai T, Freeman GJ, Gribben JG, Bernstein GM, D'Andrea AD, Ritz J, Nadler LM: Prevention of T cell anergy by signaling through the gamma c chain of the IL-2 receptor. Science 1994, 266:1039-1042.
42. Gu XX, Yue FY, Kovacs CM, Ostrowski MA: The role of cytokines which signal through the common gamma chain cytokine receptor in the reversal of HIV specific CD4(+) and CD8(+) T cell anergy. PLoS One 2007, 2:e300.

43. Hodi FS, O'Day SJ, McDermott DF, Weber RW, Sosman JA, Haanen JB, Gonzalez R, Robert C, Schadendorf D, Hassel JC, Akerley W, van den Eertwegh AJ, Lutzky J, Lorigan P, Vaubel JM, Linette GP, Hogg D, Ottensmeier CH, Lebbé C, Peschel C, Quirt I, Clark JI, Wolchok JD, Weber JS, Tian J, Yellin MJ, Nichol GM, Hoos A, Urba WJ: Improved survival with ipilimumab in patients with metastatic melanoma. N Engl J Med 2010, 363:711-723.

44. Vinay DS, Kwon BS: Immunotherapy of cancer with 4-1BB. Mol Cancer Ther 2012, 11:1062-1070.

45. Jensen SM, Maston LD, Gough MJ, Ruby CE, Redmond WL, Crittenden M, Li Y, Puri S, Poehlein CH, Morris N, Kovacsovics-Bankowski M, Moudgil T, Twitty C, Walker EB, Hu HM, Urba WJ, Weinberg AD, Curti BD, Fox BA: Signaling through OX40 enhances antitumor immunity. Semin Oncol 2010, 37:524-532.

46. Suntharalingam G, Perry MR, Ward S, Brett SJ, Castello-Cortes A, Brunner $\mathrm{MD}$, Panoskaltsis N: Cytokine storm in a phase 1 trial of the anti-CD28 monoclonal antibody TGN1412. N Engl J Med 2006, 355:1018-1028.

47. Simpson TR, Li F, Montalvo-Ortiz W, Sepulveda MA, Bergerhoff K, Arce F, Roddie C, Henry JY, Yagita H, Wolchok JD, Peggs KS, Ravetch JV, Allison JP, Quezada SA: Fc-dependent depletion of tumor-infiltrating regulatory $T$ cells co-defines the efficacy of anti-CTLA-4 therapy against melanoma. J Exp Med 2013, 210:1695-1710.

48. Harlin H, Kuna TV, Peterson AC, Meng Y, Gajewski TF: Tumor progression despite massive influx of activated CD8(+) T cells in a patient with malignant melanoma ascites. Cancer Immunol Immunother 2006, 55:1185-1197.

49. Mortarini R, Piris A, Maurichi A, Molla A, Bersani I, Bono A, Bartoli C, Santinami M, Lombardo C, Ravagnani F, Cascinelli N, Parmiani G, Anichini A: Lack of terminally differentiated tumor-specific CD8+ T cells at tumor site in spite of antitumor immunity to self-antigens in human metastatic melanoma. Cancer Res 2003, 63:2535-2545.

50. Appay V, Jandus C, Voelter V, Reynard S, Coupland SE, Rimoldi D, Lienard D, Guillaume P, Krieg AM, Cerottini JC, Romero P, Leyvraz S, Rufer N, Speiser DE: New generation vaccine induces effective melanoma-specific CD8+ T cells in the circulation but not in the tumor site. J Immuno/ 2006, 177:1670-1678.

51. Driessens G, Kline J, Gajewski TF: Costimulatory and coinhibitory receptors in anti-tumor immunity. Immunol Rev 2009, 229:126-144.

52. Gajewski TF: Cancer immunotherapy. Mol Oncol 2012, 6:242-250.

53. Spranger S, Spaapen RM, Zha Y, Williams J, Meng Y, Ha TT, Gajewski TF: Up-Regulation of PD-L1, IDO, and Tregs in the Melanoma Tumor Microenvironment Is Driven by CD8+ T Cells. Sci Trans/ Med 2013, 5:200ra116.

54. Chen LJ, Zheng X, Shen YP, Zhu YB, Li Q, Chen J, Xia R, Zhou SM, Wu CP Zhang XG, Lu BF, Jiang JT: Higher numbers of T-bet(+) intratumoral lymphoid cells correlate with better survival in gastric cancer. Cancer Immunol Immunother 2013, 62:553-561.

55. Ishida Y, Agata Y, Shibahara K, Honjo T: Induced expression of PD-1, a novel member of the immunoglobulin gene superfamily, upon programmed cell death. EMBO J 1992, 11:3887-3895.

56. Blank C, Kuball J, VoelkI S, Wiendl H, Becker B, Walter B, Majdic O, Gajewski TF, Theobald M, Andreesen R, Mackensen A: Blockade of PD-L1 (B7-H1) augments human tumor-specific T cell responses in vitro. Int J Cancer 2006, 119:317-327.

57. Iwai $Y$, Ishida M, Tanaka $Y$, Okazaki T, Honjo T, Minato N: Involvement of PD-L1 on tumor cells in the escape from host immune system and tumor immunotherapy by PD-L1 blockade. Proc Natl Acad Sci U S A 2002, 99:12293-12297.

58. Iwai Y, Terawaki S, Honjo T: PD-1 blockade inhibits hematogenous spread of poorly immunogenic tumor cells by enhanced recruitment of effector T cells. Int Immunol 2005, 17:133-144

59. Hirano F, Kaneko K, Tamura H, Dong H, Wang S, Ichikawa M, Rietz C, Flies DB, Lau JS, Zhu G, Tamada K, Chen L: Blockade of B7-H1 and PD-1 by monoclonal antibodies potentiates cancer therapeutic immunity. Cancer Res 2005, 65:1089-1096.

60. Zou W, Chen L: Inhibitory B7-family molecules in the tumour microenvironment. Nat Rev Immunol 2008, 8:467-477.

61. Berger R, Rotem-Yehudar R, Slama G, Landes S, Kneller A, Leiba M, KorenMichowitz M, Shimoni A, Nagler A: Phase I safety and pharmacokinetic study of CT-011, a humanized antibody interacting with PD-1, in patients with advanced hematologic malignancies. Clin Cancer Res 2008, 14:3044-3051. 
62. Brahmer JR, Tykodi SS, Chow LQ, Hwu WJ, Topalian SL, Hwu P, Drake CG, Camacho LH, Kauh J, Odunsi K, Pitot HC, Hamid O, Bhatia S, Martins R, Eaton K, Chen S, Salay TM, Alaparthy S, Grosso JF, Korman AJ, Parker SM, Agrawal S, Goldberg SM, Pardoll DM, Gupta A, Wigginton JM: Safety and activity of anti-PD-L1 antibody in patients with advanced cancer. N Engl J Med 2012, 366:2455-2465.

63. Topalian SL, Hodi FS, Brahmer JR, Gettinger SN, Smith DC, McDermott DF, Powderly JD, Carvajal RD, Sosman JA, Atkins MB, Leming PD, Spigel DR, Antonia SJ, Horn L, Drake CG, Pardoll DM, Chen L, Sharfman WH, Anders RA, Taube JM, McMiller TL, Xu H, Korman AJ, Jure-Kunkel M, Agrawal S, McDonald D, Kollia GD, Gupta A, Wigginton JM, Sznol M: Safety, Activity, and Immune Correlates of Anti-PD-1 Antibody in Cancer. N Engl J Med 2012, 366:2443-2454.

64. Patnaik A, Kang SP, Tolcher AW, Rasco DW, Papadopoulos KP, Beeram M, Drengler R, Chen C, Lon S, Perez C, Gergich K, Lehnert M: Phase I study of MK-3475 (anti-PD-1 monoclonal antibody) in patients with advanced solid tumors. J Clin Oncol 2012, 30 (Suppl; abstr 2512).

65. Thompson RH, Zang X, Lohse CM, Leibovich BC, Slovin SF, Reuter VE, Cheville JC, Blute ML, Russo P, Kwon ED, Allison JP: Serum-soluble B7x is elevated in renal cell carcinoma patients and is associated with advanced stage. Cancer Res 2008, 68:6054-6058.

66. Zang $X$, Thompson RH, Al-Ahmadie HA, Serio AM, Reuter VE, Eastham JA, Scardino PT, Sharma P, Allison JP: B7-H3 and B7x are highly expressed in human prostate cancer and associated with disease spread and poor outcome. Proc Natl Acad Sci U S A 2007, 104:19458-19463.

67. Loo D, Alderson RF, Chen FZ, Huang L, Zhang W, Gorlatov S, Burke S, Ciccarone V, Li H, Yang Y, Son T, Chen Y, Easton AN, Li JC, Rillema JR, Licea M, Fieger C, Liang TW, Mather JP, Koenig S, Stewart SJ, Johnson S, Bonvini E, Moore PA: Development of an Fc-enhanced anti-B7-H3 monoclonal antibody with potent antitumor activity. Clin Cancer Res 2012, 18:3834-3845.

68. Godin-Ethier J, Hanafi LA, Piccirillo CA, Lapointe R: Indoleamine 2,3dioxygenase expression in human cancers: clinical and immunologic perspectives. Clin Cancer Res 2011, 17:6985-6991.

69. Frumento G, Rotondo R, Tonetti M, Damonte G, Benatti U, Ferrara GB: Tryptophan-derived catabolites are responsible for inhibition of $T$ and natural killer cell proliferation induced by indoleamine 2,3-dioxygenase. J Exp Med 2002, 196:459-468.

70. Munn DH, Sharma MD, Lee JR, Jhaver KG, Johnson TS, Keskin DB, Marshall B, Chandler P, Antonia SJ, Burgess R, Slingluff CL Jr, Mellor AL: Potential regulatory function of human dendritic cells expressing indoleamine 2 , 3-dioxygenase. Science 2002, 297:1867-1870.

71. Uyttenhove C, Pilotte L, Théate I, Stroobant V, Colau D, Parmentier N, Boon $T$, Van den Eynde BJ: Evidence for a tumoral immune resistance mechanism based on tryptophan degradation by indoleamine 2, 3-dioxygenase. Nat Med 2003, 9:1269-1274.

72. Liu X, Shin N, Koblish HK, Yang G, Wang Q, Wang K, Leffet L, Hansbury MJ, Thomas B, Rupar M, Waeltz P, Bowman KJ, Polam P, Sparks RB, Yue EW, Li Y, Wynn R, Fridman JS, Burn TC, Combs AP, Newton RC, Scherle PA: Selective inhibition of IDO1 effectively regulates mediators of antitumor immunity. Blood 2010, 115:3520-3530.

73. Newton RC, Scherle PA, Bowman K, Liu X, Beatty GL, O'Dwyer PJ, Gajewski T, Bowman J, Schaub R, Leopold L: Pharmacodynamic assessment of INCB024360, an inhibitor of indoleamine 2,3-dioxygenase 1 (IDO1), in advanced cancer patients. J Clin Oncol 2012, 30:18 (Suppl; abstr 2500^).

74. NCT01195311 A Phase I, Open-Label, Dose-Escalation Study to Determine the Safety, Tolerability, Pharmacokinetics and Pharmacodynamics of INCB024360 in Patients With Advanced Malignancies. http://clinicaltrials.gov/ct2/show/ NCT01195311.

75. NCT01604889 A Phase 1/2 Randomized, Blinded, Placebo Controlled Study of Ipilimumab in Combination With INCB024360 or Placebo in Subjects With Unresectable or Metastatic Melanoma. http://clinicaltrials.gov/ct2/show/ NCT01604889.

76. Soliman HH, Neuger A, Noyes D, Vahanian NN, Link CJ, Munn D, Streicher H, Sullivan D, Antonia S: A phase I study of 1-methyl-D-tryptophan in patients with advanced malignancies. J Clin Oncol 2012, 30. Suppl; abstr 2501.

77. NCT00617422 1-Methyl-D-Tryptophan in Treating Patients With Metastatic or Refractory Solid Tumors That Cannot Be Removed By Surgery. [http:// clinicaltrials.gov/ct2/show/NCT00567931]

78. NCT01191216 1-Methyl-D-Tryptophan and Docetaxel in Treating Patients With Metastatic Solid Tumors. [http://clinicaltrials.gov/ct2/show/NCT01191216? term=1-Methyl-D-Tryptophan\&rank=3]
79. Raber P, Ochoa AC, Rodríguez PC: Metabolism of L-arginine by myeloidderived suppressor cells in cancer: mechanisms of T cell suppression and therapeutic perspectives. Immunol Invest 2012, 41:614-634.

80. Hori S, Nomura T, Sakaguchi S: Control of regulatory T cell development by the transcription factor Foxp3. Science 2003, 299:1057-1061.

81. Kryczek I, Liu R, Wang G, Wu K, Shu X, Szeliga W, Vatan L, Finlayson E, Huang E, Simeone D, Redman B, Welling TH, Chang A, Zou W: FOXP3 defines regulatory $T$ cells in human tumor and autoimmune disease. Cancer Res 2009, 69:3995-4000.

82. Ichihara F, Kono K, Takahashi A, Kawaida H, Sugai H, Fujii H: Increased populations of regulatory $\mathrm{T}$ cells in peripheral blood and tumorinfiltrating lymphocytes in patients with gastric and esophageal cancers. Clin Cancer Res 2003, 9:4404-4408.

83. Liyanage UK, Moore $\Pi$, Joo HG, Tanaka Y, Herrmann V, Doherty G, Drebin JA, Strasberg SM, Eberlein TJ, Goedegebuure PS, Linehan DC: Prevalence of regulatory $T$ cells is increased in peripheral blood and tumor microenvironment of patients with pancreas or breast adenocarcinoma. J Immunol 2002, 169:2756-2761.

84. Okita R, Saeki T, Takashima S, Yamaguchi Y, Toge T: CD4 + CD25+ regulatory $T$ cells in the peripheral blood of patients with breast cancer and non-small cell lung cancer. Oncol Rep 2005, 14:1269-1273.

85. Adeegbe DO, Nishikawa H: Natural and induced T regulatory cells in cancer. Front Immunol 2013, 4:190.

86. Sato E, Olson SH, Ahn J, Bundy B, Nishikawa H, Qian F, Jungbluth AA, Frosina D, Gnjatic S, Ambrosone C, Kepner J, Odunsi T, Ritter G, Lele S, Chen YT, Ohtani H, Old LJ, Odunsi K: Intraepithelial CD8+ tumor-infiltrating lymphocytes and a high CD8+/regulatory T cell ratio are associated with favorable prognosis in ovarian cancer. Proc Natl Acad Sci U S A 2005, 102:18538-18543.

87. Kline J, Brown IE, Zha YY, Blank C, Strickler J, Wouters H, Zhang L, Gajewski TF: Homeostatic proliferation plus regulatory T-cell depletion promotes potent rejection of B16 melanoma. Clin Cancer Res 2008, 14:3156-3167.

88. Rech AJ, Vonderheide RH: Clinical use of anti-CD25 antibody daclizumab to enhance immune responses to tumor antigen vaccination by targeting regulatory T cells. Ann N Y Acad Sci 2009, 1174:99-106.

89. Sutmuller RP, van Duivenvoorde LM, van Elsas A, Schumacher TN, Wildenberg ME, Allison JP, Toes RE, Offringa R, Melief CJ: Synergism of cytotoxic T lymphocyte-associated antigen 4 blockade and depletion of CD25(+) regulatory T cells in antitumor therapy reveals alternative pathways for suppression of autoreactive cytotoxic T lymphocyte responses. J Exp Med 2001, 194:823-832.

90. Rasku MA, Clem AL, Telang S, Taft B, Gettings K, Gragg H, Cramer D, Lear SC, McMasters KM, Miller DM, Chesney J: Transient T cell depletion causes regression of melanoma metastases. J Transl Med 2008, 6:12.

91. Ansell SM, Tang H, Kurtin PJ, Koenig PA, Nowakowski GS, Nikcevich DA, Nelson GD, Yang Z, Grote DM, Ziesmer SC, Silberstein PT, Erlichman C, Witzig TE: Denileukin diftitox in combination with rituximab for previously untreated follicular B-cell non-Hodgkin's lymphoma. Leukemia 2012, 26:1046-1052.

92. Atchison E, Eklund J, Martone B, Wang L, Gidron A, Macvicar G, Rademaker A, Goolsby C, Marszalek L, Kozlowski J, Smith N, Kuzel TM: A pilot study of denileukin diftitox (DD) in combination with high-dose interleukin-2 (IL-2) for patients with metastatic renal cell carcinoma (RCC). $J$ Immunother 2010, 33:716-722.

93. Attia P, Maker AV, Haworth LR, Rogers-Freezer L, Rosenberg SA: Inability of a fusion protein of IL-2 and diphtheria toxin (Denileukin Diftitox, DAB389IL-2, ONTAK) to eliminate regulatory T lymphocytes in patients with melanoma. J Immunother 2005, 28:582-592.

94. Telang S, Rasku MA, Clem AL, Carter K, Klarer AC, Badger WR, Milam RA, Rai SN, Pan J, Gragg H, Clem BF, McMasters KM, Miller DM, Chesney J: Phase II trial of the regulatory $T$ cell-depleting agent, denileukin diftitox, in patients with unresectable stage IV melanoma. BMC Cancer 2011, 11:515.

95. Rech AJ, Mick R, Martin S, Recio A, Aqui NA, Powell DJ Jr, Colligon TA, Trosko JA, Leinbach LI, Pletcher CH, Tweed CK, DeMichele A, Fox KR, Domchek SM, Riley JL, Vonderheide RH: CD25 blockade depletes and selectively reprograms regulatory $\mathrm{T}$ cells in concert with immunotherapy in cancer patients. Sci Transl Med 2012, 4:134ra62.

96. Lu T, Gabrilovich DI: Molecular pathways: tumor-infiltrating myeloid cells and reactive oxygen species in regulation of tumor microenvironment. Clin Cancer Res 2012, 18:4877-4882.

97. Gabrilovich DI, Nagaraj S: Myeloid-derived suppressor cells as regulators of the immune system. Nat Rev Immunol 2009, 9:162-174. 
98. Chappert P, Schwartz RH: Induction of T cell anergy: integration of environmental cues and infectious tolerance. Curr Opin Immunol 2010, 22:552-559

99. Kwon ED, Hurwitz AA, Foster BA, Madias C, Feldhaus AL, Greenberg NM, Burg MB, Allison JP: Manipulation of T cell costimulatory and inhibitory signals for immunotherapy of prostate cancer. Proc Natl Acad Sci U S A 1997, 94:8099-8103.

100. Chen L, McGowan P, Ashe S, Johnston JV, Hellström I, Hellström KE: B7-1/CD80transduced tumor cells elicit better systemic immunity than wild-type tumor cells admixed with Corynebacterium parvum. Cancer Res 1994, 54:5420-5423.

101. Gajewski TF, Fallarino F, Uyttenhove C, Boon T: Tumor rejection requires a CTLA4 ligand provided by the host or expressed on the tumor: superiority of B7-1 over B7-2 for active tumor immunization. J Immunol 1996, 156:2909-2917.

102. Wang LX, Li R, Yang G, Lim M, O'Hara A, Chu Y, Fox BA, Restifo NP, Urba WJ, Hu HM: Interleukin-7-dependent expansion and persistence of melanoma-specific T cells in lymphodepleted mice lead to tumor regression and editing. Cancer Res 2005, 65:10569-10577.

103. Klebanoff CA, Khong HT, Antony PA, Palmer DC, Restifo NP: Sinks, suppressors and antigen presenters: how lymphodepletion enhances $T$ cell-mediated tumor immunotherapy. Trends Immunol 2005, 26:111-117.

104. Brown IE, Blank C, Kline J, Kacha AK, Gajewski TF: Homeostatic proliferation as an isolated variable reverses CD8+ T cell anergy and promotes tumor rejection. J Immunol 2006, 177:4521-4529.

105. Rosenberg SA, Yang JC, Sherry RM, Kammula US, Hughes MS, Phan GQ, Citrin DE, Restifo NP, Robbins PF, Wunderlich JR, Morton KE, Laurencot CM, Steinberg SM, White DE, Dudley ME: Durable complete responses in heavily pretreated patients with metastatic melanoma using T-cell transfer immunotherapy. Clin Cancer Res 2011, 17:4550-4557.

106. Zheng Y, Zha Y, Driessens G, Locke F, Gajewski TF: Transcriptional regulator early growth response gene 2 (Egr2) is required for T cell anergy in vitro and in vivo. J Exp Med 2012, 209:2157-2163.

107. Zheng Y, Zha Y, Gajewski TF: Molecular regulation of T-cell anergy. EMBO Rep 2008, 9:50-55

108. Zha Y, Marks R, Ho AW, Peterson AC, Janardhan S, Brown I, Praveen K, Stang S, Stone JC, Gajewski TF: T cell anergy is reversed by active Ras and is regulated by diacylglycerol kinase-alpha. Nat Immunol 2006, 7:1166-1173.

109. Zheng Y, Zha Y, Spaapen RM, Mathew R, Barr K, Bendelac A, Gajewski TF: Egr2-dependent gene expression profiling and ChIP-Seq reveal novel biologic targets in T cell anergy. Mol Immunol 2013. doi:10.1016/j. molimm.2013.03.006 [Epub ahead of print].

110. Triebel F, Jitsukawa S, Baixeras E, Roman-Roman S, Genevee C, ViegasPequignot $\mathrm{E}$, Hercend T: LAG-3, a novel lymphocyte activation gene closely related to CD4. J Exp Med 1990, 171:1393-1405.

111. Sierro S, Romero P, Speiser DE: The CD4-like molecule LAG-3, biology and therapeutic applications. Expert Opin Ther Targets 2011, 15:91-101.

112. Kwon BS, Weissman SM: CDNA sequences of two inducible T-cell genes. Proc Natl Acad Sci U S A 1989, 86:1963-1967.

113. Anderson AC: Tim-3, a negative regulator of anti-tumor immunity. Curr Opin Immunol 2012, 24:213-216.

114. Baghdadi M, Nagao H, Yoshiyama H, Akiba H, Yagita H, Dosaka-Akita H, Jinushi M: Combined blockade of TIM-3 and TIM-4 augments cancer vaccine efficacy against established melanomas. Cancer Immunol Immunother 2013, 62:629-637.

115. Grosso JF, Kelleher CC, Harris TJ, Maris CH, Hipkiss EL, De Marzo A, Anders R, Netto G, Getnet D, Bruno TC, Goldberg MV, Pardoll DM, Drake CG: LAG-3 regulates $\mathrm{CD} 8+\mathrm{T}$ cell accumulation and effector function in murine self- and tumor-tolerance systems. J Clin Invest 2007, 117:3383-3392.

116. Kuang $Y$, Weng $X$, Liu X, Zhu H, Chen Z, Jiang B, Chen H: Anti-tumor immune response induced by dendritic cells transduced with truncated PSMA IRES 4-1BBL recombinant adenoviruses. Cancer Lett 2010, 293:254-262.

117. Gajewski TF, Fuertes M, Spaapen R, Zheng Y, Kline J: Molecular profiling to identify relevant immune resistance mechanisms in the tumor microenvironment. Curr Opin Immunol 2011, 23:286-292.

118. Tarhini AA, Gogas H, Kirkwood JM: IFN-a in the treatment of melanoma. J Immunol 2012, 189:3789-3793.

119. Tarhini AA, Cherian J, Moschos SJ, Tawbi HA, Shuai Y, Gooding WE, Sander C, Kirkwood JM: Safety and efficacy of combination immunotherapy with interferon alfa- $2 \mathrm{~b}$ and tremelimumab in patients with stage IV melanoma. J Clin Oncol 2012, 30:322-328. Erratum in: J Clin Oncol 2012, 30:3903.
120. Burnette $B C$, Liang $H$, Lee $Y$, Chlewicki L, Khodarev NN, Weichselbaum RR, Fu YX, Auh SL: The efficacy of radiotherapy relies upon induction of type i interferon-dependent innate and adaptive immunity. Cancer Res 2011, 71:2488-2496.

121. Grauer OM, Molling JW, Bennink E, Toonen LW, Sutmuller RP, Nierkens S, Adema GJ: TLR ligands in the local treatment of established intracerebral murine gliomas. J Immunol 2008, 181:6720-6729.

122. Wang $Y$, Zhu M, Yu P, Fu YX: Promoting immune responses by LIGHT in the face of abundant regulatory $T$ cell inhibition. J Immunol 2010, 184:1589-1595.

123. Zou W, Zheng H, He TC, Chang J, Fu YX, Fan W: LIGHT delivery to tumors by mesenchymal stem cells mobilizes an effective antitumor immune response. Cancer Res 2012, 72:2980-2989.

124. Miyamoto S, Inoue H, Nakamura T, Yamada M, Sakamoto C, Urata Y, Okazaki T, Marumoto T, Takahashi A, Takayama K, Nakanishi Y, Shimizu H, Tani K: Coxsackievirus B3 is an oncolytic virus with immunostimulatory properties that is active against lung adenocarcinoma. Cancer Res 2012, 72:2609-2621

125. Amgen Press Release: Amgen Announces Top-Line Results Of Phase 3 Talimogene Laherparepvec Trial In Melanoma. http://www.amgen.com/ media/media_pr_detail.jsp?releaselD=1798143.

126. Xu L, Xu W, Jiang Z, Zhang F, Chu Y, Xiong S: Depletion of CD4(+)CD25(high) regulatory $T$ cells from tumor infiltrating lymphocytes predominantly induces Th1 type immune response in vivo which inhibits tumor growth in adoptive immunotherapy. Cancer Biol Ther 2009, 8:66-72.

127. Klages K, Mayer CT, Lahl K, Loddenkemper C, Teng MW, Ngiow SF, Smyth MJ, Hamann A, Huehn J, Sparwasser T: Selective depletion of Foxp3+ regulatory $T$ cells improves effective therapeutic vaccination against established melanoma. Cancer Res 2010, 70:7788-7799.

128. Duraiswamy J, Laluza KM, Freeman GJ, Coukos G: Dual blockade of PD-1 and CLTA-4 combined with tumor vaccine effectively restores T-cell rejection function in tumors. Cancer Res 2013, 73(12):3591-603.

129. Kocak E, Lute K, Chang X, May KF Jr, Exten KR, Zhang H, Abdessalam SF, Lehman AM, Jarjoura D, Zheng P, Liu Y: Combination therapy with antiCTL antigen-4 and anti-4-1BB antibodies enhances cancer immunity and reduces autoimmunity. Cancer Res 2006, 66:7276-7284.

130. Woo SR, Turnis ME, Goldberg MV, Bankoti J, Selby M, Nirschl CJ, Bettini ML, Gravano DM, Vogel P, Liu CL, Tangsombatvisit S, Grosso JF, Netto G, Smeltzer MP, Chaux A, Utz PJ, Workman CJ, Pardoll DM, Korman AJ, Drake CG, Vignali DA: Immune inhibitory molecules LAG-3 and PD-1 synergistically regulate $\mathrm{T}$-cell function to promote tumoral immune escape. Cancer Res 2012, 72:917-927.

131. Sakuishi K, Apetoh L, Sullivan JM, Blazar BR, Kuchroo VK, Anderson AC: Targeting Tim-3 and PD-1 pathways to reverse T cell exhaustion and restore anti-tumor immunity. J Exp Med 2010, 207:2187-2194.

132. NCT00703105 Defining the Role of CD4 + CD25+ Immunoregulatory T-cells in the Treatment of Patients With Advanced Ovarian Cancer Who Receive Dendritic Cell Based Vaccine Therapies. http://clinicaltrials.gov/ct2/show/ NCT00703105.

133. NCT00515528 Randomized Phase II Study of Multipeptide Vaccination With or Without Regulatory T Cell Depletion Using Ontak in Patients With Metastatic Melanoma. [http://clinicaltrials.gov/ct2/show/NCT00515528]

134. NCT01307618 Vaccine Therapy With or Without Interleukin-12 Followed by Daclizumab in Treating Patients With Metastatic Melanoma. [http:// clinicaltrials.gov/ct2/show/NCT01307618]

135. NCT01844505 A Phase 3, Randomized, Double-Blind Study of Nivolumab Monotherapy or Nivolumab Combined With Ipilimumab Versus Ipilimumab Monotherapy in Subjects With Previously Untreated Unresectable or Metastatic Melanoma. [http://clinicaltrials.gov/ct2/show/NCT01844505]

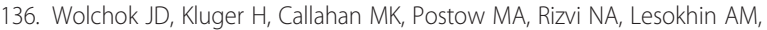
Segal NH, Ariyan CE, Gordon RA, Reed K, Burke MM, Caldwell A, Kronenberg SA, Agunwamba BU, Zhang X, Lowy I, Inzunza HD, Feely W, Horak CE, Hong Q, Korman AJ, Wigginton JM, Gupta A, Sznol M: Nivolumab plus ipilimumab in advanced melanoma. N Engl J Med 2013, 369:122-133.

137. Gajewski TF, Louahed J, Brichard VG: Gene signature in melanoma associated with clinical activity: a potential clue to unlock cancer immunotherapy. Cancer J 2010, 16:399-403.

138. Ji RR, Chasalow SD, Wang L, Hamid O, Schmidt H, Cogswell J, Alaparthy S, Berman D, Jure-Kunkel M, Siemers NO, Jackson JR, Shahabi V: An immuneactive tumor microenvironment favors clinical response to ipilimumab. Cancer Immunol Immunother 2012, 61:1019-1031. 
139. Louahed J, Gruselle O, Gaulis S, Coche T, Eggermont AM, Kruit W, Dreno B, Chiarion Sileni VC, Lehmann F, Brichard VG: Expression of defined genes identified by pretreatment tumor profiling: association with clinical responses to the GSK MAGE-A3 immunotherapeutic in metastatic melanoma patients (EORTC 16032-18031). J Clin Oncol 2008, 26. Suppl; abstr 9045).

140. Sullivan RJ, Hoshida Y, Brunet J, Tahan S, Aldridge J, Kwabi C, Gardiner E, McDermot D, Golub T, Atkins MA: A single center experience with highdose IL-2 treatment for patients with advanced melanoma and pilot investigation of a novel gene expression signature as a predictor of response. J Clin Oncol 2009, 27:15S. Abstract 9003.

141. Taube JM, Anders RA, Young GD, Xu H, Sharma R, McMiller TL, Chen S, Klein AP, Pardoll DM, Topalian SL, Chen L: Colocalization of inflammatory response with B7-h1 expression in human melanocytic lesions supports an adaptive resistance mechanism of immune escape. Sci Trans/ Med 2012, 4:127ra37.

doi:10.1186/2051-1426-1-16

Cite this article as: Spranger and Gajewski: Rational combinations of immunotherapeutics that target discrete pathways. Journal for

ImmunoTherapy of Cancer 2013 1:16.

\section{Submit your next manuscript to BioMed Central and take full advantage of:}

- Convenient online submission

- Thorough peer review

- No space constraints or color figure charges

- Immediate publication on acceptance

- Inclusion in PubMed, CAS, Scopus and Google Scholar

- Research which is freely available for redistribution

Submit your manuscript at www.biomedcentral.com/submit 